\title{
DEVELOPING CYBERCOUNSELING FOR JOB SECTOR SELECTION
}

\author{
Sri Mulyati ${ }^{1)}$, Novi Setiani ${ }^{2)}$, Uly Gusniarti ${ }^{3)}$ \\ 1,2) Teknik Informatika,Fakultas Teknologi Industri, Universitas Islam Indonesia \\ Jl.Kaliurang Km 14 Yogyakarta \\ 3) Psikologi, Fakultas Psikologi dan Sosial Budaya, Universitas Islam Indonesia \\ Jl.Kaliurang Km 14 Yogyakarta \\ E-Mail:mulya@uii.ac.id,novi.setiani@uii.ac.id,uly.gusniarti@uii.ac.id
}

\begin{abstract}
ABSTRAK
Dalam institusi pendidikan tinggi mahasiswa disiapkan untuk siap bekerja. Pada pendidikan tinggi ini terdapat mahasiswa yang memiliki usia yang cukup matang untuk mengambil keputusan, namun sering ditemui masalah bahwa mahasiswa kesulitan memilih pekerjaan dan merencanakan karir. Mahasiswa perlu mengotimalkan keahlian-keahlian sesuai pekerjaan yang akan datang dengan mengenali tipe kepribadiannya sehingga dapat mendukung keberhasilan pemilihan pekerjaan. Di lapangan, sering terjadi masalah kurangnya bimbingan karir oleh konselor kepada mahasiswa sehingga mahasiswa kurang dapat mengoptimalkan potensi yang dimilikinya. Oleh karena itu, diperlukan sarana yang dapat membantu kedua belah pihak melakukan komunikasi dalam ranah konseling bimbingan karir.Solusi yang ditawarkan dalam penelitian ini adalah melalui pembuatan sistem cybercounseling. Sistem ini memfasilitasi mahasiswa dan konselor untuk berkomunikasi, mengenali kepribadian mahasiswa melalui pengukuran berbasis Myers-Brigs Type Indicator (MBTI), dan rekomendasi bidang pekerjaan yang sesuai dengan kepribadian mahasiswa. Pengukuran ini akan dilakukan dalam sistem berbasis komputer sehingga klasifikasi kepribadian dapat diketahui oleh konselor dan mahasiswa. Sistem pakar ini dapat dijadikan sebagai dukungan pengambilan keputusan untuk menempatkan ke bidang pekerjaan yang sesuai.
\end{abstract}

Kata Kunci: mahasiswa, karir, optimal, keahlian, cybercounseling

\section{ABSTRACT}

In the institution of higher education students are prepared to be ready to work. In this higher education, there are students who have age enough to make decisions. Multiple students are having trouble choosing a job and planning a career. Optimizing future job-appropriate skills by recognizing personality types can support successful job selection. In the field, there is often a problem of lack of career guidance by counselors to students so that students are less able to optimize their potential. Therefore, it is necessary a tool that can help both parties to communicate in the realm of career counseling. The solution offered in this research is through the creation of cybercounseling system. A fairly comprehensive method of measuring personality types is the Myers-Brigs Type Indicator (MBTI). This measurement will be done in a computer-based system so that the personality classification can be known by the counselor and students. This expert system can be used as decision support to put into the appropriate field of work.

Keywords: student, career, optimal, skill, cybercounseling

\section{PENDAHULUAN}

Pada institusi pendidikan tinggi mahasiswa disiapkan untuk siap bekerja. Pada pendidikan tinggi ini terdapat mahasiswa yang memiliki usia yang cukup matang untuk mengambil keputusan. Banyak mahasiswa yang kesulitan memilih pekerjaan dan merencanakan karir. Salah satu alasan mahasiswa masuk perguruan tinggi karena untuk mengejar karir. Dalam hal ini mahasiswa memandang pendidikan di perguruan tinggi sebagai alat untuk mencapai tujuan profesi atau pekerjaan tertentu pada kehidupannya dimasa akan datang.

Sebagai lembaga pendidikan tinggi, kampus dituntut menghasilkan lulusan yang memiliki kompetensi sesuai dengan visi dan misinya, baik di bidang keilmuan (hard skill) dan maupun kepribadian (soft skill). Berbagai upaya telah dilakukan oleh lembaga pendidikan tinggi untuk mengembangkan kompetensi mahasiswanya, misal dengan pembaharuan kurikulum berbasis 
kompetensi, pelatihan sistematis di bidang pengembangan soft skill, dan pembekalan karir bagi calon wisudawan. Hal ini merupakan wujud implementasi penyiapan mahasiswa yang tidak hanya ahli dalam keilmuannya, tapi juga mampu mengelola diri dan berhubungan dengan orang lain. Sebagai contoh dari soft skill adalah kemampuan bekerja sama, mengambil inisiatif, keberanian mengambil keputusan dan gigih.

Mahasiswa diharapkan sudah memiliki pilihan dan keputusan mengenai karir yang akan dijalaninya setelah lulus dari program pendidikan di universitas. Pengenalan mengenai karir yang tepat dan cocok bagi setiap mahasiswa idealnya difasilitasi oleh konselor pendidikan secara kontinu. Namun, biasanya mahasiswa hanya mendapatkan pembekalan karir sebelum wisuda dalam satu sesi saja. Oleh karena itu, diperlukan sebuah media untuk mengatasi masalah ini, yaitu melalui implementasi aplikasi bidang psikologi, khususnya pada sub bidang tipe kepribadian dan pengembangan karir. Aplikasi ini dapat memberikan informasi karir yang sesuai dengan tipe kepribadian yang dimiliki. Mahasiswa dapat berkonsultasi dengan pembimbingnya, mengenali tipe kepribadiannya dan memperoleh rekomendasi alternatif karir yang sesuai kepribadiannya. Rumusan masalah dalam penelitian ini adalah bagaimana membuat sistem informasi berbasis website untuk panduan karir sesuai dengan tipe kepribadian?

Aplikasi ini dibangun dengan bertujuan membantu mahasiswa untuk mengetahui tipe kepribadiannya sehingga dapat mengambil keputusan dan melangkah lebih baik kedepannya dalam ranah akademik, memberikan informasi karir kedepannya disamping daripada itu aplikasi ini juga bertujuan membantu dosen pembimbing akademik dalam mengetahui tipe kepribadian dari mahasiswa bimbingannya sehingga dapat memberikan saran secara langsung untuk kebaikan mahasiswanya

a) Terdapat database yang mampu menyimpan data tes kepribadian mahasiswa dan contoh pekerjaan yang direkomendasikan.

b) Mahasiswa dapat mengoprimalkan potensi dengan mengetahui deskripsi tipe kepribadian yang didapatkan.

Adapun Manfaat Penelitian ini adalah :

1 Memberi gambaran kepada mahasiswa tentang prospek karir setelah lulus studi.

2 Memudahkan untuk menentukan jenis pekerjaan sesuai dengan tipe kepribadian

3 Membantu rencana pengembangan karier mahasiswa

\section{Pengukuran Psikologi}

Tes adalah instrumen atau alat dalam pengukuran. Dalam bidang psikologi khususnya, tes memegang peranan yang sangat penting bahkan hasil dari suatu tes tersebut menjadi titik acuan dalam proses pengambilan suatu keputusan. Fungsi dari tes itu sendiri adalah sebagai instrumen guna membantu dalam pengambilan suatu keputusan yang menyangkut individu maupun kelompok. Subjek dari tes tersebut adalah manusia, yang acap kali masih bingung dalam menentukan sebuah keputusan mengenai diri dan masa depannya.

Terdapat berbagai pendapat dari para ahli psikologi terkait definisi tes sebagai instrumen pengukuran yaitu: Anne Anastasi melalui bukunya yang berjudul Psychological Testing (1976) berpendapat bahwa " a psychological test is essentially an 
objective and standardized measure of a sample of behavior" yang artinya, tes merupakan alat atau instrumen pengukur yang mempunyai standar obyektif sehingga dapat digunakan secara meluas dan dapat digunakan sebagai cara untuk mengukur dan membandingkan (Azwar, 2015). Sedangkan menurut Lee J. Cronbach yang dikemukakan dalam bukunya berjudul Essential of Psychological Testing

(1970) berpendapat bahwa "...a systematic procedure for observing a person's behavior and describing it with the aid of a numerical scale or a category system" yaitu tes merupakan suatu prosedur yang sistematis untuk mengamati dan membandingkan tingkah laku dua orang atau lebih serta menggambarkannya dengan bantuan skala numerik atau kategorisasi (Azwar, 2015).

Tes disini dimaksudkan untuk mengukur kepribadian seseorang dan membantu mengetahui tipe kepribadian seperti apa yang ia miliki. Hasil tipe kepribadian tersebut bisa dijadikan sebagai patokan dasar dalam menentukan keputusan. Tujuan dari tes kepribadian itu sendiri adalah sebagai alat untuk mengetahui perbedaan diantara setiap kepribadian, kepribadian disini bersifat individual dimana tidak ada seorang pun yang mempunyai kepribadian sama antara satu dengan yang lainnya bahkan dalam kondisi terlahir kembar sekalipun. Hasil dari tes kepribadian bukanlah suatu hal yang baik atau buruk adanya, bukan pula suatu yang benar atau salah, melainkan kepribadian adalah apa yang terdapat pada diri seseorang yang bersifat khas dan unik. Berbeda dari tes-tes yang lain, tes kepribadian ini ditujukan untuk mengetahui dan menganalisa perbedaan tingkah laku seseorang.

\section{MBTI (Myers_Briggs Type Indicaor)}

Myers - Briggs Type Indicator atau disingkat MBTI merupakan sebuah instrumen pengukuran berbentuk kuisioner yang digunakan untuk membaca tipe kepribadian seseorang dalam lingkungannya. Myers - Briggs Type Indicator adalah instrumen psikotes yang dirancang untuk mengukur preferensi psikologis seseorang dalam melihat dunia dan membuat sebuah keputusan. Dalam penggunaannya, instrumen psikotes ini dibangun untuk mengukur kecerdasan individu, bakat dan tipe kepribadian seseorang.

Awal mulanya pada tahun 1962, Isabel Myers bersama ibunya meringkas buku tipe psikologi karya Carl Gustav Jung yang kemudian oleh mereka diperbaharui dan dinamakan dengan MBTI atau Myers-Brigg Type Indicator dimana bertujuan untuk membuat instrumen psikotes yang mengukur tipe kepribadian manusia dan menggolongkannya ke dalam 16 tipe kepribadian yang berbeda (Naisaban, 2003).

Instrumen Psikotes MBTI (MyersBriggs Type Indicator) sendiri mempunyai skema psikologis yang bertumpu pada empat dimensi utama yang saling berlawanan yaitu tipe kepribadian Extrovert yang berlawanan denga Introvert, tipe kepribadian Sensing yang berlawanan dengan Intuitive, tipe kepribadian Thinking yang berlawanan dengan Feeling dan tipe kepribadian Judging yang berlawanan dengan Perceiving.

\section{Pilar Pendidikan Unesco}

Ada empat pilar pendidikan yang dicanangkan UNESCO (Delors, 1996) apabila diterapkan dengan baik di perguruan tinggi akan mampu membekali mahasiswa dengan kecakapan hidup yang dibutuhkan untuk bekal hidup di masyarakat. Empat pilar pendidikan itu adalah belajar untuk mengetahui (learning to know), belajar untuk 
berbuat (learning to do), belajar untuk menjadi jati diri (learning to be), dan belajar untuk hidup bermasyarakat dalam damai (learning to live together). Hal tersebut apabila diterapkan di perguruan tinggi dengan baik makan akan menciptakan lulusan yang berkualitas yang dapat menunjang kemajuan bangasa indonesia.

\section{Cyber Counseling}

Cyber Counseling adalah salah satu strategi bimbingan dan konseling yang bersifat virtual atau konseling yang berlangsung melalui bantuan koneksi internet. Dalam hal ini proses konseling berlangsung melalui internet dalam bentuk web-site, e-mail, facebook, videoconference (yahoo messangger) dan ide inovatif laninnya. Proses konseling menggunakan cyber counseling atau counseling maya artinya konselor bersama klien tidak hadir secara fisik pada ruang dan waktu yang sama.

Layanan bimbingan konseling berbasis web site ini memuat layanan informasi berkenaan bimbingan karir dan pengenalan diri. Aplikasi ini dapat memberikan arahan bimbingan karir karena terdapat data karir di setiap tipe kepribadian. sebagai contoh yang memiliki tipe kerptibadian ESFJ : beauticians, healthworker, office manager, secretaries dan teacher

\section{METODE}

\section{Analisis Kebutuhan}

Analisis kebutuhan meliputi analisis masalah, menentukan tujuan penelitian, analisa sistem, perancangan sistem, dan pengembangan sistem.

a. Ruang lingkup analisis masalah adalah dengan menganalisa variabel yang terlibat untuk digunakan dalam menentukan pekerjaan.

b. Menentukan tujuan penelitian, penelitian ini bertujuan untung konseling karir mahasiswa

c. Perancangan sistem berbasis web dengan menggunakan alat ukur tes MBTI.

d. Pengembangan sistem dengan melakukan pengkodean untuk membangun sistem.

e. Pengujian sistem dilakukan dengen pengujian black box testing

f. Pengumpulan Data dengan menggunakan sistem.

\section{Perancangan Database}

Terdapat beberapa tabel yang dapat digunakan untuk membuat aplikasi Cybercounseling ini. Database ini mengakomodasi supaya sistem bersifat dinamis dan dapat disimpan pada database .

Adapun tabel yang dimaksud adalah :

1. Tabel Soal digunakan untuk menyimpan data pertanyaan.

2. Tabel Kategori digunakan untuk menyimpan kategori dari parameter pengukuran

3. Tabel Versi digunakan untuk menyimpan versi alat ukur yang dikembangkan.

4. Tabel Mahasiswa digunakan untuk menyimpan data siswa.

5. Tabel DPA digunakan untuk menyimpan data Dosen pembimbing Akademik.

6. Tabel tahun ajaran digunakan untuk menyimpan tahun ajaran

7. Tabel Ujian digunaka untuk menyimpan hasio TES

8. Tabel tipe dan karir digunakan untuk menyimpan data tipe kepribadian dan karir .

Adapun relasi tabelnya dapat dilihat pada 
gambar 1 berikut ini :

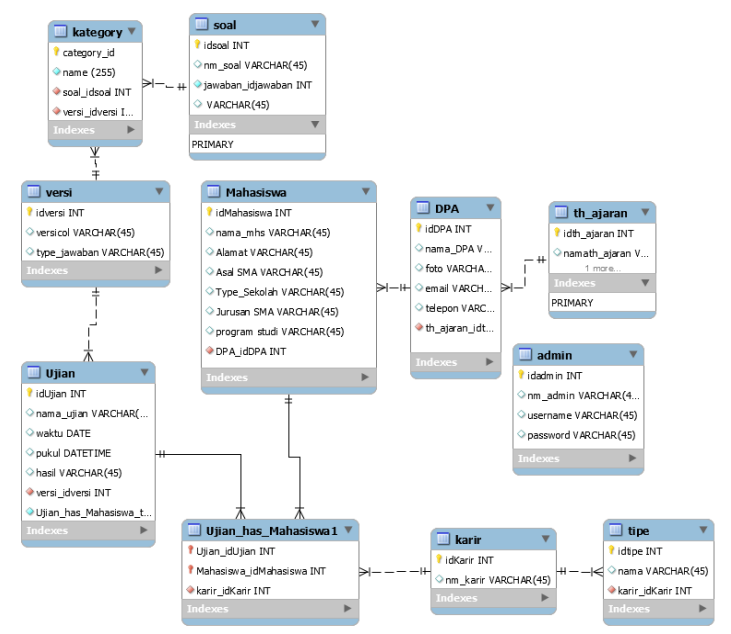

Gambar 1. Perancangan Database

\section{Desain Sistem}

Pengukuran MBTI pada awalnya dilakukan melalui media kertas. Terdapat empat dimensi pengukuran, dimana setiap dimensi terdiri dari 20 pertanyaan. dimensi tersebut adalah Extrovert yang berlawanan denga Introvert, tipe kepribadian Sensing yang berlawanan dengan Intuitive, tipe kepribadian Thinking yang berlawanan dengan Feeling dan tipe kepribadian Judging yang berlawanan dengan Perceiving. seperti terlihat pada Gambar 2.

\section{a) sistem awal}

Pada sistem awal ini masih menggunakan kertas. Sehingga memiliki resiko terjadinya kerusakan dan membutuhkan waktu yang lama untuk mengkoreksi.

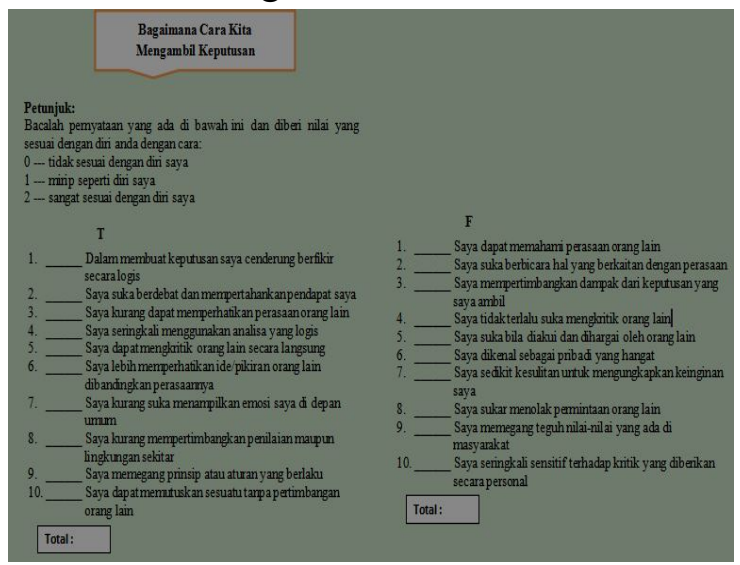

Gambar 2. Pengukuran MBTI
Pada penelitian ini, dihasilkan sistem berbasis web untuk mengukur tipe kepribadian berbasis MBTI dan rekomendasi karir. Hasil implementasi sistem dapat dilihat pada Gambar 3.

\section{b) Sistem baru}

Pada sistem baru ini dibangun menggunakan website.

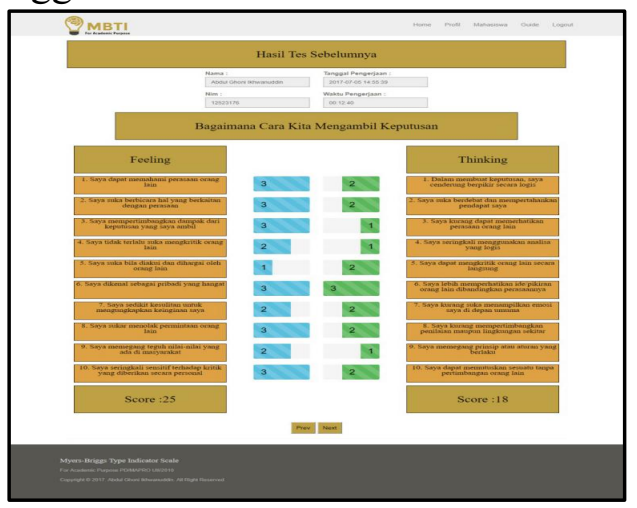

Gambar 3.soal pengukuran tipe kepribadian berbasis WEB

\section{c) Tabel Hubungan Tipe kepribadian dan Pilihan Karir}

Berikut ini adalah contoh tabel hubungan tipe kepribadian dengan pilihan kesamaan karir yang ditemukan dari banyak organisasi Tabel 1. Hubungan tipe kepribadian dan pilihan karir.

\begin{tabular}{|c|c|c|c|}
\hline $\mathrm{N}$ & Tipe & Keterangan & $\begin{array}{l}\text { Jenis } \\
\text { Pilihan } \\
\text { karir }\end{array}$ \\
\hline 1 & ISTJ & $\begin{array}{l}\text { - Praktis, } \\
\text { logis dan } \\
\text { realistis. } \\
\text { - Lebih } \\
\text { mudah } \\
\text { mengingat } \\
\text { informasi } \\
\text { dalam bentuk } \\
\text { fakta. } \\
\text {-Dapat }\end{array}$ & $\begin{array}{l}\text { Acountans. } \\
\text { auditor, } \\
\text { Engginer, } \\
\text { Financial, } \\
\text { Manager } \\
\text { Police } \\
\text { Officer, } \\
\text { Stellworke } \\
\text { rs }\end{array}$ \\
\hline
\end{tabular}




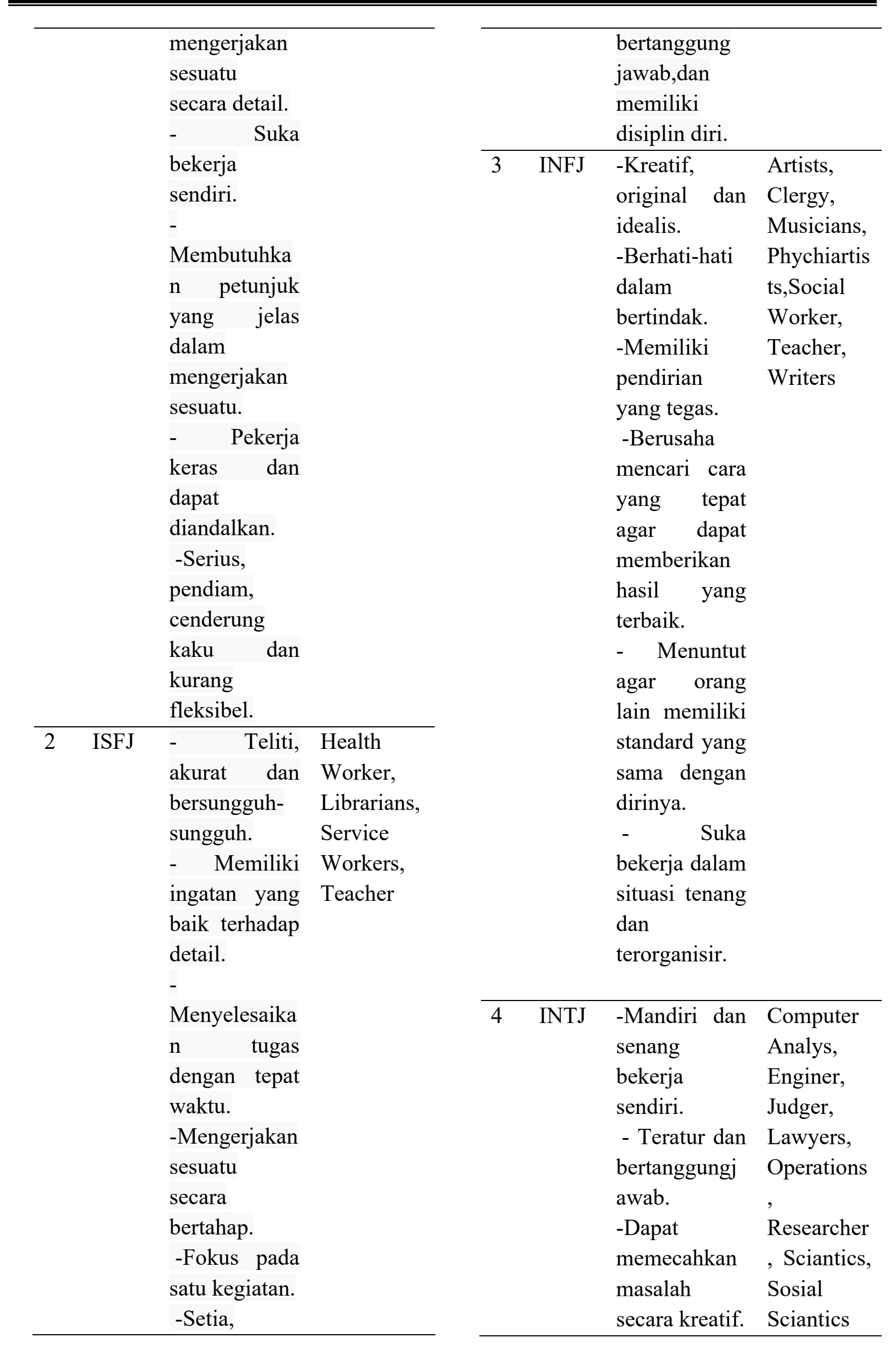




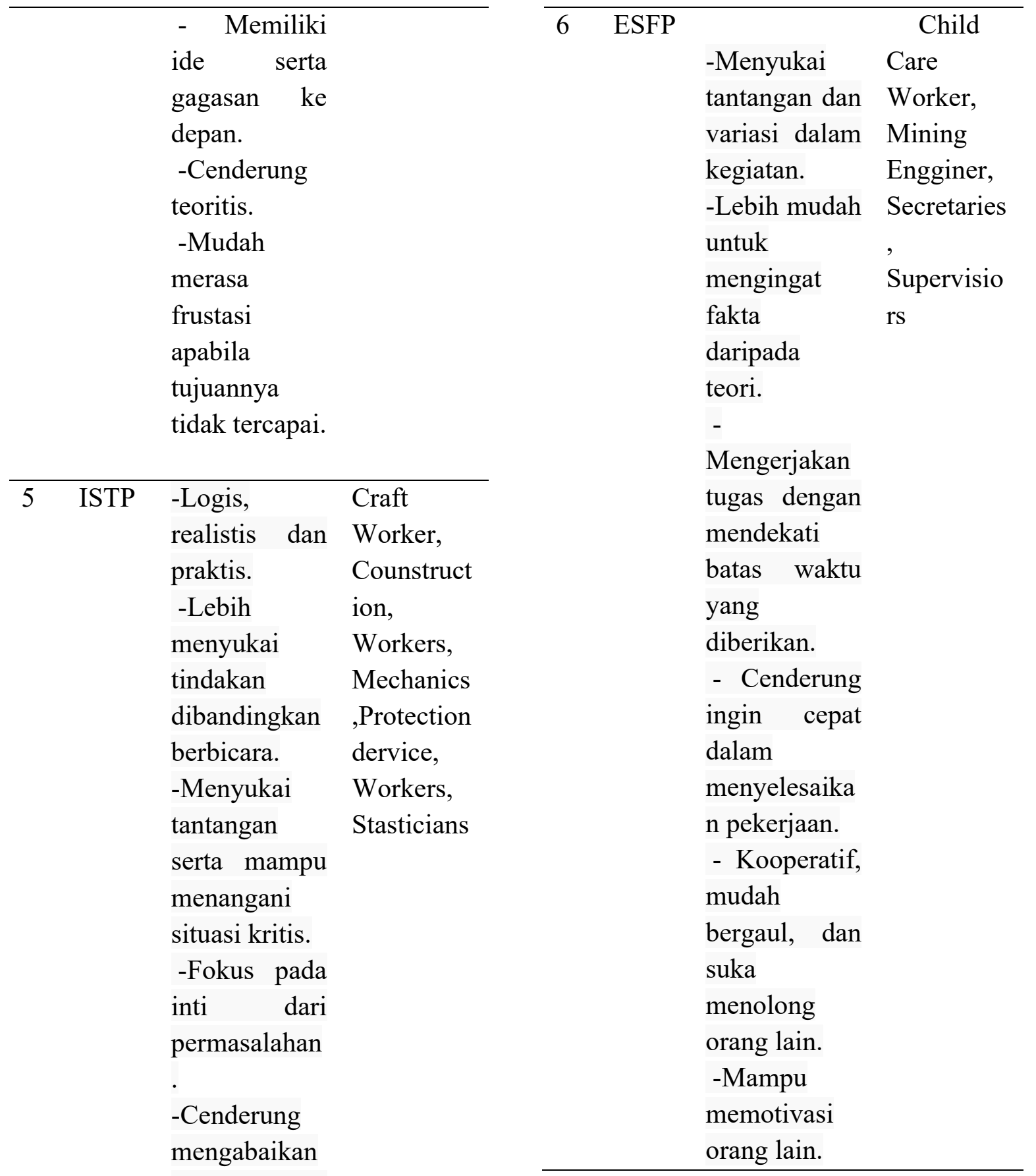

aturan dalam

mencapai

\section{HASIL}

tujuannya.

-Tidak suka

Hasil penelitian ini berupa aplikasi diawasi cybercounseling untuk pemilihan pekerjaan dengan menggunakan alat ukur MBTI.

dalam

bekerja.

Sistem diujikan kepada pengguna -Memilih

bekerja sendiri. mahasiswa dan dapat dilihat detailnya seperti pada gambar 4. Sistem ini memiliki fitur untuk melihat hasil tes dengan informasi waktu pengerjaan dan durasinya. keterangan tipe kepribadian, nilai dari 4 aspek 
pengukuran dan disertai dengan nilai dominan masing-masing aspek sebagai hasil dari pengukuran, adapun hasil pengukuranya sebagai berikut :

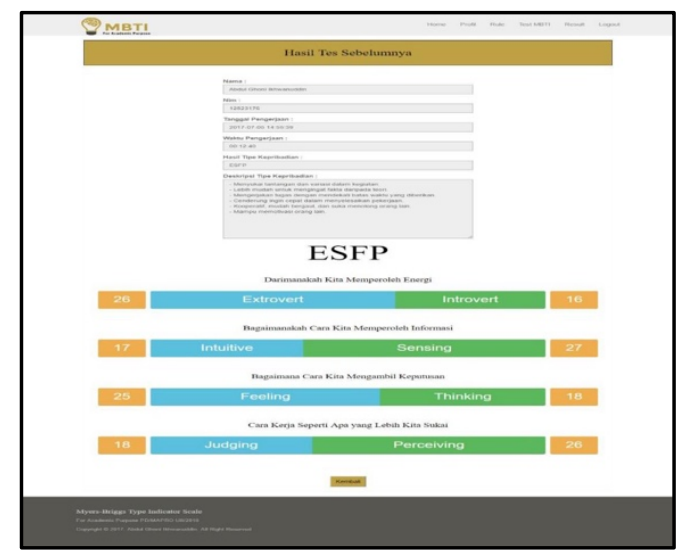

Gambar 4. Hasil Pengukuran dari MBTI

sebagai detail keterangan dari hasil tes tipe kepribadian ESFP merupakan tipe kepribadian seorang extrovert yang merasakan dengan menggunakan pengindra (Sensing), membuat keputusan dan menarik kesimpulan dengan perasaan (Feeling) serta melihat dunia luar dengan melakukan pengamatan (Perceiving). Seseorang dengan tipe kepribadian ESFP (PD/MAPRO UII, 2010) merupakan orang yang menyukai perubahan dan variasi dalam setiap kegiatan yang dilakukan, mereka lebih mudah untuk mengingat fakta daripada teori, mereka mempunyai kebiasaan yaitu dengan mengerjakan tugas dengan mendekati batas waktu yang ditentukan dan cenderung ingin cepat dalam menyelesaikan tugas atau pekerjaan tersebut. Orang dengan tipe kepribadian ini merupakan orang yang kooperatif, mudah bergaul dan suka akan menolong orang lain dan mampu dalam memotivasi serta memberi semangat kepada orang lain.

Layanan bimbingan konseling berbasis web site ini memuat layanan informasi berkenaan bimbingan karir dan pengenalan diri , dari hasil test tersebut terdapat rekomendasi jenis pekerjaan yang sesuai yaitu Child Care Worker, Mining Engginer, Secretaries, Supervisiors.

\section{KESIMPULAN}

Adapun kesimpulan yang didapatkan dari penelitian ini adalah :

a) Telah dibuat sistem cybercounseling yang dapat memfasilitasi mahasiswa dan konselor untuk berkomunikasi, mengenali kepribadian mahasiswa melalui pengukuran berbasis MyersBrigs Type Indicator (MBTI), dan rekomendasi bidang pekerjaan yang sesuai dengan kepribadian mahasiswa.

b) Pengukuran dilakukan dalam sistem berbasis komputer sehingga klasifikasi kepribadian dapat diketahui oleh konselor dan mahasiswa terkait pekerjaan yang sesuai dengan tipe kepribadian.

\section{DAFTAR PUSTAKA}

[1] PD/MAPRO UII. (2010). Myers-Briggs Type Indicator Scale For Academic Purpose. Yogyakarta: Magister Program Psikologi Pendidikan, Universitas Islam Indonesia.

[2] Azwar, 2003, "Penyusunan Skala Psikologi”,Yogyakarta : Pustaka Pelajar

[3] Delors J. et al. (1996). L'E' ducation. Un tre'sor est cache' dedans. Paris: $E^{\prime}$ ditions UNESCO - Odile Jacob. The English version of this report, often referred to as "the Delors report" is entitled Learning: The treasure within. Report to UNESCO of the international commission on education for the twentyfirst century. Paris: UNESCO.

[4] Naisaban, L. (2003). Psikologi Jung. Jakarta: Grasindo

[5] Sharf, Richard S (1992). Applying Career Development Theory to Counseling. California:Thomson Broke/Cole Publising Company. 